\title{
THE WREATH OF ROMANTIC FRAGMENTS. DANTE AND LISZT
}

\section{Olena Roshchenko}

\section{INTRODUCTION}

The purpose of this study, designed as a "chain or wreath of fragments" (according to F. Schlegel), is to establish creative parallels between Dante and Liszt based on the restoration of the continuum of discretely organized biographies of the geniuses. The study is based on the principle of alternating fragments of creative biographies of Dante and Liszt, resulting in a special type of the dialogue, presented in the form of a "wreath of fragments". The "links of the chain" of biographical fragments are determined by the stages of the path of Dante and Liszt to creating prophetic visions of the afterlife in the "Divine Comedy". The oeuvres of geniuses as "fragments of a general confession" (according to J. W. von Goethe) supplement the events of their biographies.

This work is based on the method of comparative biographies dating back to Plutarch, transformed under the influence of genre features of a romantic fragment. A romantic "example" of the design of comparative biographies is the novel by E. T. A. Hoffmann (1821), in the art field of whom the fragments of "biographical scripts" 3 are combined - the crazy Kapellmeister Johannes Kreisler and the Tomcat Murr.

The aphoristic nature and Universalism, analytism and symbolism, art and science, philosophy and theology, myth and history, endless and finite, ironic and tragic interact in the genre of a romantic fragment ${ }^{4}$. In the fragment genre, F. Schlegel ("Critical Fragments", 1797) put forward the concept of romantic irony - the embodiment of the artist's inner freedom, "Fragmentary genius", "The spirit of transcendental buffoonery", allowing you to rise "above all that is conditioned, including your own art, virtue, and genius"5. The purpose of

${ }^{1}$ Schlegel F. (1990) From the Athenaic Fragments. Zarubezhnaya literatura 19th veka. Romantizm [Foreign literature of the 19th century. Romanticism]. Moscow. P. 42. (in Russian)

${ }^{2}$ Goethe J. W. (1975) From my life. Poetry and truth. Moscow: Iskusstvo. P. 606. (in Russian)

${ }^{3}$ Savitskaya N. V. (2009) Age-related aspects of composer's life-creation. (dissertation of Doctor of Art Studies). Kyiv: P. I. Tchaikovsky National Music Academy. 414 p. (in Ukrainian)

${ }^{4}$ Roshchenko E. G. (2000) Concepts of the finite and infinite in the philosophy and art of romanticism. Problems of personal orientation of pedagogical process (collection of scientific works). Kharkov. P. 194-205. (in Russian)

Roshchenko E. G. (2000) The genesis of the romantic fragment genre. Theory and practice of pedagogical process. (collection of scientific works). Kiev. P. 218-228. (in Russian)

5 De Sanctis F. (1963) History of Italian literature. In 2 vols. Vol. 1. Moscow. P. 38 (in Russian) 
romantic poetry is the fusion of poetry and philosophy, rhetoric, prose, "genius and criticism", is achievable, according to F. Schlegel, thanks to the involvement of the genre laws of the fragment. In the cycles of fragments created by Novalis ("Blüthenstaub", "Glauben und Liebe", 1798; "Das allgemeine Broullion or General Draft", 1798-1799; "Logological Fragments", 1799-1800), the ideas of magical idealism, mutual transition of all things, total symbolism are approved.

The autobiographical poetry and prose of romanticism experienced the genre influences of the fragment. J. W. von Goethe called his works "the fragments of a general confession ("Bruchstücke einer grossen Konfession"), which should be complemented by his autobiography" ". The impact of fragmented dramaturgy is reflected in the autobiographical work of G. Byron ("Detached Thoughts", 1821), the unfinished novel by M. Weber "The Artist's Life" (18), the works of G. Flaubert ("Agony" 1838; "Notes of a Madman", 1839; "The secret Thoughts", 1838-1841), who wrote the story of his life in an aphoristic manner, capturing his own self-portrait in it - a skeptic, idealist, dreamer, madman, mystic, lyricist, philosopher. Charles Augustin Sainte-Beuve, the creator of the "method of artistic biographical criticism"7 and "Father of literary biography" in the diary works ("Thoughts", "Fragments", "Maxims") addressed the genre of the fragment in the design of autobiographical experiences. In his legacy the biographical method develops into the autobiographical one. Charles Augustin Sainte-Beuve did not create a single portrait, in which he would not be reflected; drawing someone else, the critic created his own portrait.

The relevance of fragmented framed comparative biographies of Dante and Liszt is due to the importance of the autobiographical method in the oeuvres of geniuses. Dante's autobiographical method showed itself directly (the author is the character of the work), Liszt's indirectly, as a means of selfidentification of the author and his character as a way of revealing the theme of the artist's life and his art.

\section{Biographical fragments}

The name of Dante immortalized in the image of Beatrice "Vita nova" and "Divina Commedia" is covered with legends. The love and death of Donna, her transformation into an angel, her return to Empireius is the sacred center of Dante's life-creation, uniting the fragments of his biography into a single

\footnotetext{
${ }^{6}$ Zhirmunsky V. M. (1987) From the history of Western European literature. Selected Works. Leningrad: Nauka. P. 30 (in Russian)

${ }^{7}$ Grechanaya E. Charles Augustin Sainte-Beuve (1804-1869). Foreign history and theory of literature of the $19-20^{\text {th }}$ centuries Treatises, articles, essays. University of Moscow. K. 87. P. 445-449. (in Russian)
} 
"chain". The ideal of an omnipotent woman spiritualized the mystery of love. Boccaccio in his work "The Life of Dante" (1357-1362) formed the tradition of mythologizing of the Poet's life creation, surrounding his name with legends. The halo of myth-making around the "Divine Comedy" shone in the era of romanticism ${ }^{8}$. The conditionality of Dante's poem by providence was emphasized by the romanticists: "The prophetic poem of Dante is the only system of transcendental poetry in its highest incarnation", reads 247 of F. Schlegel's "Athenaic fragments"'.

In the book "On the origin, life, works and customs of the illustrious man of Dante Alighieri, the famous Florentine poet, and on the works he created" ${ }^{\prime 10}$, Boccaccio pointed out both the greatest qualities of the soul peculiar to the "amazing poet", "the reservoir of virtues and knowledge"11, i.e. "the sublime structure of the mind and rich imagination" 12 , and the vice - the desire for glory, "arrogance and importance"13. The interaction of factual and mythological plans conveys the features of fragmentary composition to Boccaccio's work. The legend's invasion of Dante's life appeared in the sacralization of its fragments.

Boccaccio gives the stories from the life of the Poet, which served as the mythologization of his biography. The visage of the Poet is mythologized. The Verona women recognized in him the man that "he goes down to Inferno and returns from there when he pleases, and brings the news of those who languish there"; the confirmation of this is a curly beard and a darkened face, as if scorched by an inferno ${ }^{14}$.

The sacralization of the name of Dante is the basis for the formation of mythology around the image of the Poet. According to Boccaccio, the name of Dante "justified itself in everything" "15; "his name, polished by time, like a blade that has been in many battles, will shine brighter and brighter"16. The mother's prophetic dream, similar to "the Lord's will"17, set out at the beginning and end of the "Biography", completed by "The Interpretation of

${ }^{8}$ Roshchenko E. G. (2000) The first cycle of the romantic myth of Dante and the sonata fantasy of F. Liszt. Music art and culture. Scientific Bulletin. in. 1. Odessa: Astroprint. P. 59-67. (in Russian)

${ }^{9}$ Schlegel F. (1990) From the Athenaic Fragments. Foreign literature of the 19th century. Romanticism. Moscow. P. 44. (in Russian)

${ }^{10}$ Boccaccio G. (1968) The Life of Dante. Mini works. Moscow, p. 572. (in Russian).

${ }^{11}$ Ibid. P. 559.

${ }^{12}$ Boccaccio G. (1968) The Life of Dante. Mini works. Moscow. P. 549.

${ }^{13}$ Ibid. P. 557.

${ }^{14}$ Ibid. P. 547.

${ }^{15}$ Ibid. P. 524.

${ }^{16}$ Ibid. P. 567.

${ }^{17}$ Ibid. P. 568 
Sleep"18. Justifying the idea of matching the personality and name, Boccaccio follows in the footsteps of Dante: subjecting Beatrice's name to the sacralization in the "Vita nova", the Poet believed that this was what she should be called.

Legend stories accompanied the most important stages of the Poet's life: birth, love, exile, death, which took place "on the very day when the church celebrates the Exaltation of the Holy Cross". The poet's "weary soul" ascended to heaven, which Beatrice "embraced" to taste "the happiness that has no end and limit"19.

The formation of the biography-myth was promoted by what became of the initial and final songs of "Divina commedia". A miracle is like their return from oblivion. Exiled from Florence, the Poet lost the first seven songs of "Inferno" and stopped working on the poem. When the initial songs were returned to the author, he recalled "a once thought out plan and $\langle\ldots\rangle$ translate it into poetry" 20 .

The destiny of the final thirteen songs of the poem is connected with a dream. The poet did not have time to make them public, "for he had suddenly died". But "eight months after the death of the poet", his son Jacopo had a wonderful dream. "... His father Dante appeared to him in a dream..."21. Taking Jacopo by the hand, the father "led to the chamber, where he had previously slept, and said, pointing to the wall: "Here you will find what you are looking for" ${ }^{\prime 22}$. In the niche of the bedroom those "thirteen songs were found that they were desperate to find" ${ }^{\prime 23}$. The revival of the end of the poem is also associated with Divine Providence.

The Dante theme - the cross-cutting in the works of F. Liszt - is represented by a one-part fantasy sonata for piano (1837), a two-part vocal symphony (1857), and an organ triptych (the year of creation is unknown). In each of the "parts" of the musical macrotrilogy, the "Divine Comedy" received a peculiar philosophical, genre, timbre and cyclical interpretation. Liszt's triple appeal to the confession poem of the original genius is due to the reflection of the image of the Wanderer Poet, who rushed in spiritual wandering to the Transcendent, the saving Ewigweibliche.

Liszt's appeal to the "Divine Poem" is connected with the names of two women. Creating a sonata-fantasy is associated with Marie d'Agoult - the inspirer of the first half of the composer's life; the writing of the "Dante

\footnotetext{
${ }^{18}$ Ibid. P. 568-572.

${ }^{19}$ Ibid. P. 540.

${ }^{20}$ Boccaccio G. (1968) The Life of Dante. Mini works. Moscow. P. 562-563.

${ }^{21}$ Ibid. P. 563.

${ }^{22}$ Ibid. P. 564.

${ }^{23}$ Ibid.
} 
Symphony" and the organ triptych "Dante" - with the love for Carolyne zu Sayn-Wittgenstein.

The first evidence of Liszt's involvement in Dante's legacy is in the diary of the composer's father, Adam Liszt. The comparisons of the Hungarian genius with Mozart were full of press pages in the 20s of the 19th century. However, the genius of Liszt was considered by the contemporaries not only the eighth wonder of the world, but also a satanic offspring. "But this is a satanic child!" exclaimed on February 19, 1823 Ferdinando Paer, the director of the Italian opera, one of Liszt's teachers. The radiant-Mozartian art of F. Liszt was complemented by demonic, soaring into the heavenly spheres by the immersion into the depths of suffering - Inferno, making it possible to capture the Dante verticalization of time-space.

February 5, 1824. The impressions of the father about the first lesson of playing the organ given by Abbot Barden in the church of St. Eustache, are filled with an anticipation of Dante's visions in the musical fantasies of his son. The admiration of the father interacts with the fear caused by the divine gift of the son. Liszt-father felt the breath of an open abyss in the improvisation of his 13-year-old $\operatorname{son}^{24}$, enunciated by "many-voiced cry", experiences close to the felt ones by Dante's character on the edge of the infernal crater (see Inferno, III, 133; Inferno, IV, 7-10). 13 years later, the theme of the vision of the infernal abyss will open "Sonata after reading Dante".

In the organ improvisation of Liszt-child, the visions of Inferno are regulated by the strict frame of the Gothic cathedral. The grotesque Inferno is inscribed in the composition of Dante's poem, similar to the Gothic cathedral. Dante combined the principles of poetry and architecture. In a letter dated 1841, the composer wrote: "Music is the architecture of sounds or, perhaps, architecture is the crystallized music" 25 .

March 8, 1824. Describing the fragment of the libretto of the only opera of his son, "Don Sanche, or The Castle of Love", A. Liszt wrote: "The legendary Don Sanche would also like to enter the <...> castle, but the gatekeeper was in his way. He says: $\boldsymbol{A B A N D O N} \boldsymbol{A L L} \boldsymbol{H O P E}$. You can enter this place when the flame of mutual love touches your heart" ${ }^{\prime 26}$. The artistic codes of the libretto fragment refer to the last line of the inscription on the Gates of Dante's Inferno: "Lasciate ogni speranza" (Inferno, III, 9). The musical recording of the Dante's line will acquire the function of the leitmotif of the $1^{\text {st }}$ part of the "Dante Symphony"; F. Liszt will clarify its contents by introducing Dante's

\footnotetext{
${ }^{24}$ Gál György Sándor. (1986) List. Moscow. P. 69-70. (in Russian)

${ }^{25}$ Nádor T. (1988) If Liszt kept a diary ... Budapest. P. 118. (in Russian)

${ }^{26}$ Gál György Sándor. (1986) List. Moscow. P. 72. (in Russian)
} 
quote from "The Comedy". In Liszt's youthful opera, the doorkeeper who stopped the way to the Castle of Love in the name of passing the tests that purify the soul is like Virgil. The cited fragment of the opera libretto with the divine poem is united by the interpretation of love as incinerating fire. The Dantean associations in Liszt's opera correspond to doctastilo; the game with reminiscences and quotes testifies to the composer's allusion thinking.

1827, Paris. V. Hugo introduces F. Liszt with the essence of a romantic grotesque, based on the interaction of the beautiful and the ugly, human and animal. The grotesque method of mixing the beautiful and the ugly in the first Canticle of Dante's poem appeared in the depiction of the image of Lucifer the root cause of evil. The verticalisation of images of absolute ugliness (Inferno) and pure beauty (Paradiso) reflects the structure of medieval space.

The interaction of art and religion was instrumental in the life of Franz Liszt, reflected in the macrotrilogy, consecrated in the name of Dante. The fragments of Liszt's creative biography testify the interaction of art and religion in the composer's life. The adoption of the abbacy by Liszt (1865) was not an extravagant trick of a genius leading a secular lifestyle. For almost forty years, the artist nurtured this idea. In 1827, in an interview with the father, "St. Ferenc", pointing to the book "Following Christ", he said: "Only this can threaten my career as a musician". In 1830, F. Liszt's intention to leave for the monastery was caused by separation from Caroline de SaintCricq. Suffering the pain of bereavement of his beloved, Liszt turned into a recluse. The newspaper "L'Etoile" published a report of his death. Twenty years later (in 1837), the fate will "return" Caroline to him, in the guise of the Countess Sayn-Wittgenstein.

1830, Paris. Liszt's getting acquainted with Berlioz and "Symphonie Fantastique". In the world of "grotesque music" of the French composer, 19-year-old Liszt found a paradoxical combination of the ideal and the infernal.

On the evening of March 9, 1831, in Paris, at the height of the cholera epidemic, Paganini gave a concert, at which Liszt was present. The idea of competing with a demonic violinist occupied his thoughts: "I must ascend the summits that he has reached, and then surpass him,"27. The art of the great "Jettatore" has become the "measure of perfection" for Liszt, seeking to unravel the mystery of his artistry, embodying the transcendent virtuosity in piano art. The inspiration for Liszt of the era of the "mastery of Paganini" was the legacy of the artists of different ages and nations. In a letter to Peter Wolf, Liszt wrote: "Homer, the Bible, Plato, Locke, Byron, Hugo, Lamartine, Chateaubriand, Beethoven, Bach, Hummel, Mozart - they are all here, all

\footnotetext{
${ }^{27}$ Gál György Sándor. (1986) List. Moscow. P. 119. (in Russian)
} 
around me". Liszt's commitment to reading was determined by Abbot Lamennais: "Learning is the most dangerous of all wanderings in the world"; "Reading is a dangerous journey". The consequence of the addiction to the "dangerous wandering" was the macrotrilogy on the theme of Dante - an autobiographical poem of wanderings.

In the era of the mastery of Paganini's artistry, Liszt correlated himself with the hero of the legend of the Renaissance, in which the artistic impulse awakened the contemplation of the masterpiece of the predecessor: "“I am also an artist!" exclaimed Michelangelo, when he first saw a masterpiece. Your poor friend repeats $<\ldots>$ incessantly, after being at the Paganini concert: "What a man he is, what a violinist! What an artist!"28. In 1840, Schumann wrote about Liszt: "Not a single artist, with the exception of Paganini, is able to subjugate the audience in this way...". And in 1841, Ludwig Rellstab, after the death of the "Jettatore", wrote: "...Since the magical power of Paganini was banished to Merlin's grave, he (Liszt - O. R.) has been the greatest virtuoso of our time" 29 . The contest with Paganini in Liszt's life played a role similar to the "duel" of Virgil and Dante.

For Dante and Liszt, a creative competition with the predecessors and contemporaries presupposed two steps - to achieve and surpass the skill of rivals. Imitating the art of the ancients, surpassing the pattern, is the basis of the artistic method of the Renaissance. Dante's dreams of returning to the Italian art of perfection, and the state - of lost power led to an appeal to Roman antiquity. According to Dante, for those who wish to work out the highest syllable, "it would be most useful to get acquainted with the representative poets, <..> Virgil, Ovid's "Metamorphoses", Statius, Lucanus". Unlike "rhymers" (rimatori), Dante called the poets only them. Following the traditions for Dante is a condition for the perfection of the modern poetry: "The closer we follow the great poets, the more correctly we compose" 30 . Calling himself "the sixth" after the inhabitants of LimboHomer, Virgil, Horace, Ovid and Lucanus ("When I was initiated into their convocation / And became the sixth in the midst of so many minds", Inferno, IV, 100), Dante believed that the essence of imitation was in the "escape" from the direct imitation (the treatise "On the People's Eloquence", 1304-1307).

1835, Freiburg. The 24-year-old Liszt approached the creation of the first part of the macrotrilogy based on the "Divine Comedy" (piano fantasia guasi sonata was written in 1837). George Sand associated Liszt's organ playing of

\footnotetext{
${ }^{28}$ Ibid. P. 121.

${ }^{29}$ Nádor T. (1988) If Liszt kept a diary ... Budapest. P. 122. (in Russian)

${ }^{30}$ Dante A. (1968) On folk eloquence. Mini works. Moscow. P. 292. (in Russian)
} 
"Diesirae" from Mozart's Requiem in the Church of St. Nicholas with the poem of Dante. "It seemed that the great artist called Dante's entire Inferno and Purgatorio under the light $<\ldots>$ pointed arches. Franz's Florentine profile has never loomed <...> so pale and clean among the dark clouds of mystical horror and religious sadness"31. George Sand recognized the echoes of the infernal images of Mozart and Dante in Liszt's playing, she saw the similarity of Dante's visage in the image of "St. Ferenc". Like Dante, Liszt commanded the abyss, remaining immune to the destructive fire of the infernal whirlwinds. The great prophetess of romanticism predicted the deployment of the Dante theme in Liszt's oeuvre.

September 1837, Switzerland. During the Swiss journey, Liszt was accompanied by the volume of the "Divine Comedy", a dangerous journey through the afterlife which predetermined the birth of a musical trilogy. The fantasy sonata "After reading Dante" reflects Liszt's impressions not only from the wanderings around Italy (1837). Closing the second (Italian) cycle of "Years of wanderings", the fantasy sonata summarizes the composer's experiences coupled with the first - Swiss - circle of "wanderings". In Switzerland, Liszt made the first drafts of a sonata... The letters and diary entries of F. Liszt of that time contain the quotes from the "Divine Poem". The foundations of the Liszt's interpretation of Dante's "triple poem" were formed (as defined by A. S. Pushkin).

Inspired by the reading of the poem "at the foot of the statue of Comolli", which presented "Dante led by Beatrice",32, the 26-year-old Liszt sketched "Sonata after reading Dante". The same age was Dante, who started writing "Vita nova". Liszt regretted that Comolli "so falsely understood" the plot of the "incomparable, grandiose creation", "making Beatrice a fat, fleshly woman, from Dante - angular, emaciated <...> pauvre honteux (miserable sinner) instead of "Signor del altissimo canto" ("lord of higher poetry"), as he once called Homer" ${ }^{33}$. F. Liszt preferred not the asceticism of Comolli, but the dynamism of Michelangelo in capturing the images of "Comedy" in the visual arts. Dante's interpretation of love and beauty did not find a response in Liszt's soul. Dante's understanding of Ewigweibliche was alien to the romanticist: "The poet conceived Beatrice not as an ideal of beauty, but as an ideal of knowledge". The composer could not reconcile himself with the fact that "the spirit of a highly learned theologian, explaining dogma, cursing heresy and interpreting eternal sacraments, dwells in this charming, illuminated creature" ${ }^{34}$. Indeed, "Dante, the poet theologian, in all

\footnotetext{
${ }^{31}$ The musical aesthetics of Germany. In 2 vols. (1961) v. 1. Moscow. P. 70. (in Russian).

${ }^{32}$ Liszt F. (1959) Selected Articles. Moscow. P. 98. (in Russian)

${ }^{33}$ Ibid.

${ }^{34}$ Ibid.
} 
sophisticated doctrines", acquired the "worldly wisdom" and "cameo's favour" (as the "Bologna poet and Dante's most devoted friend" Maestro Giovanni del Virgilio called the Florentine in the epitaph ${ }^{35}$ ), interpreted the beauty of women as a reflection of Christian virtues. Truly, "Not immediately the beauty of a wise woman appears before the enamored...", wrote the first Italian poet Guido Guinizelli (1230-1276), the founder of "dolce stil nuovo", the predecessor of Dante. Following the tradition of Italian poetry, whose mother was science, Dante strove to "make science accessible through poetry" $"$. Beatrice contributes to the attainment of eternal bliss, the cosmic law of love - "the face of knowledge, the beautiful face of science", a symbol of Sophia's beauty, super-sensual wisdom. The idea of gaining love through familiarization with absolute knowledge permeates the "Divine Comedy".

Dante and Liszt were inspired by the interpretation of Ewigweibliche as the embodiment of beauty "beyond the limits of not only mortals" (Paradiso, XXX, 19). However, for Liszt, the beauty of a woman is the embodiment of not only wisdom, but also feelings. According to Liszt, a woman should, "by the power of her love" enthrall a man "along with her to heaven. Not in the realm of knowledge $\langle\ldots\rangle$ but in the realm of feeling is her power! A loving woman $\langle\ldots\rangle$ a true guardian angel of a man; a female pedant is an absurdity, dissonance that has no place in the hierarchy of beings"37. In Liszt's interpretation of Ewigweibliche Dante's and Petrarch's (bodily) concepts of beauty are combined. The embodiment of Ewigweibliche in the works of Liszt is not only Beatrice, but also Francesca. Her chaste story is a side part of "Sonata after reading Dante", the central section of the concentric part I of the "Dante Symphony", the morphology of which is inspired by the Dante's topography of "Inferno". When, at the will of the composer, the law of Inferno is suspended, - "Lasciate ogni speranza", the forces of hell do not have power over Liszt's Francesca, just as Mephistopheles is powerless before Gretchen, as well as Samael - before Agatha's pigeon purity. Putting in the centre of the funnel-shaped composition "Inferno" of the image of love and hope in the Symphony means rethinking the organization of the Dante's hell, where the centre is the "abyss of evil", "the root cause of evil", the worm "with which the world is pierced", the overthrown Lucifer. The "Inferno" Centre in Liszt's Symphony symbolizes the hope that accompanies the sinner in the hell. In the Symphony Hell, Purgatory and Paradise are united by Love. The image of Beatrice in Liszt's concepts, inseparable from the embodiment of Heavenly Beauty - Virgin Mary, is captured in the final sections of the

\footnotetext{
${ }^{35}$ Boccaccio G. (1968) The Life of Dante. Mini works. Moscow, p. 541. (in Russian)

${ }^{36}$ De Sanctis F. (1963) History of Italian literature. In 2 vols. Vol. 1. Moscow. P. 65. (in Russian)

${ }^{37}$ Liszt F. (1959) Selected Articles. Moscow. P. 98. (in Russian)
} 
macrotrilogy (in the Sonata - this is a side party in the reprise, in the Symphony and organ triptych - Magnificat).

1839, Rome. The creative plans, related to the theme of Dante, are persistently present in Franz Liszt's contemplations. The composer wrote: “... I will try to write the "Dante Symphony". Then, three years later, the "Faust" symphony < ..> And then, three more drafts: "Triumph of Death", "Comedy of Death" and

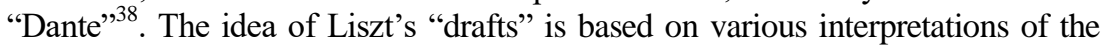
death - the triumphant, playing, overcoming wisdom of the poet-philosopher. Is the cited reference the only indication of the intent of the organ triptych "Dante" that the composer had planned to write after the Symphonies?

In a letter to G. Berlioz of October 2, 1839, Liszt wrote about the "hidden relationship between the works of geniuses", emphasizing: "Dante has found his pictorial expression in Orcagna and Michelangelo"39. The composer dreamed of creating such an embodiment of the "Divine Comedy" that would affect the eyesight, hearing and soul. The composer suggested that the music and poems would be accompanied by the picturesque paintings that revived the visions of Dante. Liszt's dreams of Gesamtkunstwerk are close to the concept of a fragment in Novalis's heritage, for whom "plastic arts, music and poetry" are "the essence of synonyms" and "relate as music, poetry and drama" ${ }^{40}$. The counterpoint of epochs in Liszt's oeuvre is expressed through a dialogue of artists. The monological genre of the poem has acquired a dialogical form. The dialogue between Dante and Virgil predetermined the significance of the mythology of going to the afterlife, formerly developed by the "dolce padre", and before him by Homer. Dante considered himself a pupil of Virgil - the Teacher of the "secrets of the sanctuaries", "the honor and light of all singers" (Inferno, VI, 67). Virgil's teacher was Homer, whose poems were guided by the author of "Aeneid". For Liszt, the Florentine poet was a Teacher, who was attracting to the upper world. In a letter dated July 8, 1856, Liszt compared Wagner's role to Virgil's mission: “... As Virgil led Dante, so you introduced me into the mysterious regions of the world of lifepierced sounds. From the bottom of my soul I am calling you: "Tu set e'l mio maestro, e'l mio autore!" "41 And I dedicate this work to you!"42. The quintiliad of artists of the Liszt's "Davidsbund" (Homer, Virgil, Dante, Liszt, Wagner) is united by the universal genre of the poem.

December 1845, Weimar. Liszt cherished the concept of the opera "Dante" on the text of J. Autran (1813-1877).

\footnotetext{
${ }^{38}$ Nádor T. (1988) If Liszt kept a diary ... Budapest. P. 91. (in Russian)

${ }^{39}$ Ibid. P. 93.

${ }^{40}$ The musical aesthetics of Germany. In 2 vols. (1961) v. 1. Moscow. P. 307. (in Russian)

41 "Have conn'd it o'er. My master thou and guide!" (Hell (or The Inferno), 1, 85).

${ }^{42}$ Nádor T. (1988) If Liszt kept a diary ... Budapest. P. 349. (in Russian)
} 


\section{Logological Fragments}

One of the genre features of a romantic fragment of a philosophical type is the restoration of the sacred role of the number. With the sacralization of the number, the restoration of the ties of music, arithmetic and mathematics, once approved by Pythagoras, is associated. The second conclusion of paragraph № 77 from the "Philosophy of Art" by F. Schelling (structural laws of fragmentary composition are characteristic of this work) contains the requirement "to explain the arithmetic side of music", since "music is the real self-enumeration of the soul - even Pythagoras linked the soul to the number - but $\langle\ldots\rangle$ the unconscious self-forgetful enumeration. Hence the definition of Leibniz: "Musica est raptus numerare se nescientis animae" ("Music is the delight of the soul, not conscious of what it considers")"43. "Back to the Pythagoreans 〈...>, to their numbers. With attention to Kepler", - also urged J. W. Ritter (1776-1810), the author of "Fragments from the Heritage of the Young Physicist" (1810), considering (in Fragment № 430) music as "the highest type of vegetation", and vegetation itself in general (Fragment № 450) as an "algebra of nature" of the fragment "Aphorisms on Art" by J. von Görres (1776-1848), a method for classifying the sounds based on mathematical laws among them is proposed: "Sounds differ mathematically in the longitude and brevity of the time they fill - this is how the poetic rhythm is constructed". J. von Görres assigned the function of the ideal of music of the future to arithmetic, combining these areas, like Leibniz and Schlegel, by the properties of the selfenumeration of the souls. "The ideal of music is arithmetic. Just as a figure $\langle\ldots\rangle$ serves as a thread from which the spirit weaves its fabric, so in music one $\langle\ldots\rangle$ tone serves as a medium in which one soul comes into contact with another" (Fragment № 62) ) $^{45}$. Like F. Schlegel, J. von Görres refreshed the teachings of Pythagoras for his modern era, turning the "system of the universe into one huge Aeolian harp" (Fragment № 69). An educated romanticist emphasized the importance of the unity between the sounds and numbers perceived by modernity from the Pythagorean doctrine, focusing on the "mathematical analysis of the universe" (Fragment № $65^{46}$ ), ordering the natural phenomena in accordance with the scale and the eternal proportion of the number.

E. T. A. Hoffman, in the 5th section, "Fantasy Pieces in Callot's Manner", the very name of which points to his inherent fragmentary character -

\footnotetext{
${ }^{43}$ Schelling F. (1966) Philosophy of art. Moscow: Mysl. 496 p. (in Russian)

${ }^{44}$ Liszt F. (1959) Selected Articles. Moscow. 333 p. (in Russian)

${ }^{45}$ The musical aesthetics of Germany. In 2 vols. (1961) v. 1. Moscow. P. 327. (in Russian)

${ }^{46}$ Ibid.
} 
"Extremely incoherent thoughts", introduced the hero's confession, indicating that "numerical relationships in music and the mysterious rules of counterpoint" cause "deep terror" in him.

"True mathematics", according to "Logological Fragments" of Novalis, reveals itself in music as a revelation, "as the creative idealism" 47 .

In the unity of music and mathematics, sound and the number - there is a manifestation of a fragment of the genre's inherent attraction to the unity of art and science, balancing the impulses of representatives of violent Romanticism to absolute freedom, the cult of fantasy, and the limit of madness.

The interpretation of the number as an act of a sacred action in the genre of a romantic fragment is due to its conjugation with a miracle. Describing mathematics as "the true element of the magician", Novalis establishes a paradoxical connection between mathematics and the miracle. "Miracles as unnatural facts are non-mathematic, but there are no such miracles, and what is called a "miracle" is understandable precisely thanks to mathematics, because nothing wonderful exists for mathematics" ("Logological Fragments" ${ }^{48}$ ). Mathematics is presented as a way to explain the miracle, and the number - as a factor in its interpretation. The sacralization of the number in poetry, music, and biography inherent in the genre of a romantic fragment heads the flow of scientific thought in this Fragment. For the role of the number as a sacred factor is significant in the content and composition of both the original Dante, and in the Liszt's concepts on the subject of Dante. The self-movement of numbers-symbols in the works of Liszt makes it possible to interpret them as a kind of mathematical epic. The patterns found in the formation of "smart numbers" (A. Dvořák), which regulate the course of two comparative biographies, attach biographical fragments not only to the biography-myth, but also to the mathematical epic. The task of discerning the manifestations of the miraculous as acts of Divine will combines the artistic and biographical manifestations of numera-sacra.

The analysis of the facts of the creative biography of Ferenc Liszt enables to conclude: Liszt's works inspired by the images of the Poet are written by will from above. This is convinced by the magical role of numbers in the sacred fragments of artists' biographies, analogies in the twists and turns of the fate of the transcendent geniuses - F. Liszt and Dante. Numbers and their transformed repetitions in the biographies of Dante and Liszt found a reflection refracted in space and time, in which the power of transformation gained the power of a metamorphosis of a mythological scale.

\footnotetext{
${ }^{47}$ Ibid. P. 305.

${ }^{48}$ Ibid. P. 305.
} 
The manifestation of the mythological miracle as the intersection of personality dimensions (according to A. F. Losev ${ }^{49}$ ) is reflected in the synchronization of fragments of creative biographies of Dante and Liszt, found in numera-sacra. The laws of numerology contribute to the objectification of parallels between the numerical foundations of the "Divine" poem, the creative lives of Dante and Liszt.

October 6, 1846. Shortly before his birthday, Liszt wrote in a letter to KarlAlexander, the Duke of Weimar: "For me there comes a moment (Nel mezzo del camnin di nostra vita - 35 years old!), when I am to break a peach of my virtuosity and release the blue-sky thinking..."50. Citing the opening line of "The Divine Comedy" ("When I had journeyed half of our life's way") on the eve of his 35th birthday, with which he associated the cessation of the concert activity of a virtuoso in the name of focusing on composing, F. Liszt correlated his artistic journey with the biography of a medieval poet who, at the same age, was on the verge of the major events. On his birthday, October 22 of the same year, Liszt wrote to his mother: " 35 years old! In the middle of my life's journey, in the middle of plans and aspirations..."51. Here, the influence of the allusive method characteristic of medieval scholarly style (doctastilo), based on both veiled and direct quotation, is noticeable. Dante's legacy was a "favourite Example" for Liszt, to which he addressed throughout his life.

According to Dante's vision set out in the treatise "Feast" ("The Banquet"), a human life is like an arc of 70 years length. Its highest point falls on its middle 35-37 years, when a person of the perfect nature, is given to comprehend the perfection of the universe and his own nature ${ }^{52}$. Dante's concept is confirmed by his life. It is also captured in the "Comedy", which depicts the image of a 35-yearold poet, that, "had already journeyed half of his life's way", began to implement the work-vision of the afterlife. A vision of the afterlife was revealed to Dante at age of 35, on Good Friday morning, March 25, 1300, when, by the decree of Pope Boniface VIII, the 1300th anniversary of the birth of Christ was celebrated, which coincided with the anniversary of the Roman Church.

In this regard, the number of poem songs found after the death of Dante acquires a symbolic meaning. The 13 final songs of Paradisi symbolically point to 1300 , marking the beginning of work on the "Divine" Poem. A twofold increase in the number 13 is associated with the beginning of the first stage of perpetuating the memory of Beatrice in the "New Life", which the poet began to

${ }^{49}$ Losev A.F. (1991) The dialectics of myth. Philosophy. Mythology. Culture. Moscow. P. 21-186. (in Russian)

${ }^{50}$ Nádor T. (1988) If Liszt kept a diary ... Budapest. P. 151-152. (in Russian)

${ }^{51}$ Nádor T. (1988) If Liszt kept a diary ... Budapest. P. 151-152. (in Russian)

${ }^{52}$ Dante A. (1968) Feast (The Banquet). Mini works. Moscow. P. 253. (in Russian) 
create at the age of 26 . At the age of 26 , Liszt created his first work on the theme of "The Divine Comedy" - "Sonata after reading Dante".

The number of the initial songs of "Comedy" left by Dante in the abandoned Florence is not less symbolic in the context of the interaction of the numerical symbols of the poem and sacred numbers preparing the life journey of the poet. 7 songs of "Inferno", after writing of which the work on the poem was temporarily interrupted, are associated with one of the main numerical characters of the first two parts of the poem: 7 deadly sins that are punished in the hell, and 7 steps of purification in the purgatory.

The 35th anniversary as the middle of life and work, the essence of which was realized by F. Liszt through matching the life of Dante, is a milestone in the life of the composer. After the concerts in Elizavetgrad (Kropyvnytskyi), F. Liszt would break up "a peach of his virtuosity" in the name of composition, "strengthening his apostolic and enlightening works of the defender of the new" "53. But this was only one of the turns in the life of the composer. On February 14, 1847, at the third concert in Kyiv, Liszt was seen and heard by Princess Carolyne zu Sayn-Wittgenstein, a "mystical charm" of whom filled "the whole second half of Liszt's life" ${ }^{\text {"54 }}$. Soon Liszt would write to Marie d'Agoult about her as "an exceptional and outstanding (very much so) woman". Carolyne's appearance in Liszt's life marked the beginning of "Vita nova" in his work, just as the glorification of Beatrice was symbolized by the initial phrase of the Initiation of the "New Life" - "Incipit Vita nova" ("A New Life Begins") in the Poet's legacy. Entering Carolyne zu Sayn-Wittgenstein into Liszt's life was the key to the realization of his musical ideas, inspired by the "Divine Comedy" by Dante - the second edition of the piano sonata, a symphony, an organ triptych.

Dante worked for 20 years on the "Divine Comedy". The previous stages of his life (the acquaintance with Beatrice, writing "Vita nova" to her death and eternal life) were the eve of the wondrous creation of the poem. The Christian interpretation of death as a harbinger of eternal and true life found the development in the art of romanticism. "Death is a romanticized principle of our life. Death is life after death. Life is enhanced through death", Novalis claimed in one of the Fragments. The interpretation of life as a prelude "to that unknown anthem, the first and solemn note of which the death will take", is reflected in F. Liszt's symphonic poem "Les Préludes" ("Preludes" or "The Beginnings"), based on the poem by A. de Lamartine (1854).

The work on the book about the New Life was started when Dante was 26 years and lasted for 10 years - until 1300, when the poet had a vision of the afterlife. In "Vita nova", Dante prophesied the creation of an unprecedented

\footnotetext{
${ }^{53}$ Glebov I. (1922) Franz Liszt. Experience of performance. Petrograd. P. 17. (in Russian)

${ }^{54}$ Ibid. P. 16.
} 
hitherto work, in which the name of his beloved would gain such a lavish praise, which not a single Donna sung by poets had known up to then. It was a dream about "Divina Commedia" that would elevate Beatrice to the universe. One hundred songs of the "Divine Comedy" would increase tenfold the sacred power of the number 10. Its introduction in the series of the sacred numbers of the poem is due to Dante's biography. 10 years separated the poet from the opportunity to contemplate the beautiful Donna - from the moment of her death to the miraculous appearance on the threshold of paradise (Purgatorio, XXX).

Liszt's familiarizing with Dante shows a striking resemblance to the milestones in the Poet's life. Divine Providence led the composer to the musical embodiment of the music pictures of the afterlife. For the first time, Dante's reminiscences appeared in the libretto of the opera of the 13-year-old Liszt. In the context of the numerical symbols of the "Divine Comedy", the age of the Liszt-child appears as a modified analogue of the number 1300 the year, when Dante had a vision of the afterlife, captured in a poem "monstrous in its correctness to the thirteen-hundredth polyhedron" equal to the number of "Paradiso" songs lost and miraculously found after the poet's death. At the age of 26, Liszt made the first sketches of "Sonata after reading Dante". The subsequent embodiment of Dante's images in Liszt's work took place at the age of 35, after getting acquainted with Carolyne. Like Dante, Liszt worked on the creation of a trilogy on the theme of the "Divine Comedy" for 20 years - from 1837, when a sketch of the piano sonata was made, to 1857 (the completion of the work on the "Dante Symphony").

Numerical symbolism, which formed the mystical basis of the "Divine Comedy", crystallized its content and form (A. Pushkin wrote that one composition of the poem was the fruit of a great genius), reflected in Dante's life, refracted variably in Liszt's biography and work.

Biographies and the oeuvres of geniuses are beautiful "with a double unity of its essence and the number" (E. Krause). They showed a pattern discovered by Novalis, the genius of fragmentation: "The highest life is mathematics"s6.

In the comparative biographies of Dante and Liszt, designed in the form of a wreath of romantic fragments, the features of a "scientifically documented biography and legends about the artist" interact, that, according to I. Barsova, "is not an alternative", since both phenomena coexist within the same cultural space. "... A legend is one of the forms of interpretation of the personality and biography of a great man in the mass consciousness, in rumour or in art - in the consciousness of one person who is able $\langle\ldots\rangle$ to subordinate the mass consciousness to the magic of an artistic image" ${ }^{\$ 57}$. Dante and Liszt are geniuses

\footnotetext{
${ }_{55}^{55}$ Mandelstam O. (1967) Talk about Dante. Moscow. P. 165. (in Russian)

${ }^{56}$ The musical aesthetics of Germany. In 2 vols. (1961). V. 1. Moscow. P. 305. (in Russian)

${ }^{57}$ Barsova I. (1988) The legend of the artist (T. Mann and G. Mahler). Music-culture - man (collection of scientific papers). Sverdlovsk: Ural University. P. 128. (in Russian)
} 
whose earthly lives, their very visage, their oeuvres are inseparable from the legends formed around them ${ }^{58}$. The interaction of the real and the legendary corresponds to the spirit of a romantic biography based on the mythologization of the image of a genius. As a result, the destruction of the line "between myth and $<\ldots>$ a biography or a description of certain episodes from the life of a person",59 occurs, which leads to the appearance of a biographical myth or a mythologized biography, a myth biography. The synchronous-diachronous examination of episodes (or fragments) of the studied biographies subjected to the mythologization contributes to the demonstration of miracle manifestations in them. According to A. F. Losev, a miracle as the intersection of personality dimensions is one of the laws of myth-making. The miracle of intersection of the personality dimensions of Dante and Liszt is born in the process of a comparative analysis of the creative biographies of geniuses removed in time: their meeting in the space of romanticism becomes inevitable. Comparative biographies of Dante and Liszt as a romantic wreath of biographical and mathematical fragments contain a series of numbers, in the sequence of which the symbolism of a miracle is embodied as the intersection of personality dimensions. The numbers 7, 13, 20, 26,35 serve a purpose of the sacred ones in the context of the comparative biographies of Dante and Liszt on course to create the "Divine Comedy".

\section{CONCLUSIONS}

A romanticized biography-myth is based on the sacralization of the name of its hero, the acquisition of his magical content: the term "unfolded magic name" expresses the essence of Losev's definition of a myth. Studying the nature of the interactions between the unfolding of the magic names of Dante and Liszt in the sacred fragments of their life-making has revealed momentous parallels, expressed by means of numerical correspondences between the events guiding the way of these geniuses to the creation of the "Divine Comedy". The facts of Liszt's creative biography related to the creation of a musical trilogy on the theme of "Divine Comedy" are as if due to the sacred symbolism of the events from Dante's life.

Numerical analogies of the sacred fragments of comparative biographies are due to the incursion of a miracle as a coincidence or clash of personality dimensions ${ }^{60}$ in the context of the biography-myths of Dante and Liszt. The manifestations of a miracle recognized at the intersection points of fragments of biographies of two geniuses acquire the meaning of "notification, displays,

\footnotetext{
${ }^{58}$ Roshchenko E. G. (2000) The first cycle of the romantic myth of Dante and the sonata fantasy of F. Liszt. Music art and culture. Scientific Bulletin. in. 1. Odessa: Astroprint. P. 59-67. (in Russian)

${ }^{59}$ Losev A.F. (1991) The dialectics of myth. Philosophy. Mythology. Culture. Moscow. P. 134. (in Russian)

${ }^{60}$ Zhirmunsky V. M. (1987) From the history of Western European literature. Selected Works. Leningrad: Nauka. P. 142 (in Russian)
} 
proclamation, testimony, sign, manifestation, prophecy"61, the signs of God's will that connected the personality dimensions of Dante and Liszt in the course of comprehending the highest truth. In the time-space of the "miracle myth" 62 the intersection of the personality dimensions of Dante and Liszt appeared in the numerical symbolism of the sacred biographical fragments.

A. F. Losev did not limit the scope of the miracle by the myth and the processes of remythologization in the post-mythological space. Losev's interpretation of a miracle lies within his meaning as a "method of interpreting historical events" in the research ${ }^{63}$. Based on the role of a miracle, Losev's way of knowing and interpreting the "wreath of fragments" in the fragments of the creative biographies of Dante and Liszt, synchronously-diachronously arranged in time and space, which acquired a sacred character under the influence of the magic role of numbers, is a methodological "support" of this study.

\section{SUMMARY}

The purpose of this study, designed in the form of a "chain or wreath of fragments" (according to F. Schlegel), is to reveal the creative parallels between Dante and Liszt based on the restoration of the continuum of discretely organized biographies of the geniuses. The study is based on the principle of alternating fragments of creative biographies of geniuses. The links of the chain of biographical fragments are determined by the transitions of Dante and Liszt to creating the visions of the underworld in the "Divine Comedy". The creations of the geniuses complement the events of their biographies. The study is based on the method of comparative biographies, transformed under the influence of genre features of a romantic fragment. Liszt's familiarizing with Dante shows a resemblance to the milestones in the Poet's life. The numerical symbolism that formed the mystical basis of the "Divine Comedy", reflected in the life of Dante, refracted variably in Liszt's biography and work. Comparative biographies of Dante and Liszt as a romantic wreath of biographical and mathematical fragments contain a series of numbers, in the sequence of which the symbolism of a miracle is embodied as the intersection of personality dimensions. The numbers $7,13,20,26,35$ serve a purpose of the sacred ones in the context of the comparative biographies of Dante and Liszt on course to create the "Divine Comedy".

\footnotetext{
${ }^{61}$ Ibid. P. 147.

${ }^{62}$ Ibid. P. 136.

${ }^{63}$ Losev A. F. (1991) The dialectics of myth. Philosophy. Mythology. Culture. Moscow. P. 147. (in Russian)
} 


\section{REFERENCES}

1. Barsova I. (1988) Legenda o khudozhnike (T. Mann i G. Mahler) [The legend of the artist (T. Mann and G. Mahler). Muzyka - kultura - chelovek (sbornik nauchnykh trudov) [Music - culture - man (collection of scientific papers)]. Sverdlovsk: Ural University. P. 128-148. (in Russian).

2. Boccaccio G. (1968) Zhizn Dante [The Life of Dante]. Malye proizvedeniya [Mini works]. Moscow, p. 521-572. (in Russian).

3. Gál György Sándor. (1986) List [List]. Moscow. 416 p. (in Russian).

4. Goethe J. W. (1975) Iz moej zhizni. Pojezija i pravda [From my life. Poetry and truth]. Moscow: Iskusstvo. 606 p. (in Russian).

5. Glebov I. (1922) Franz Liszt. Opyt kharakteristiki [Franz Liszt. Experience of performance]. Petrograd. 62 p. (in Russian).

6. Grechanaya E. Charles Augustin Sainte-Beuve (1804-1869). Zarubezhnaya istoriya i teoriya literatury $19-20^{\text {th }} v$ v. Traktaty, statyi, esse. [Foreign history and theory of literature of the $19-20^{\text {th }}$ centuries Treatises, articles, essays]. University of Moscow. K/87. P. 445-449. (in Russian).

7. Dante A. (1968) O narodnom krasnorechii [On folk eloquence]. Malye proizvedeniya [Mini works]. Moscow. (in Russian).

8. Dante A. (1968) Pir [Feast (The Banquet)]. Malye proizvedeniya [Mini works]. Moscow. P. 112-269. (in Russian).

9. Zhirmunsky V. M. (1987) Iz istorii zapadnoevropeyskikh literatur [From the history of Western European literature]. Izbrannye trudy [Selected Works]. Leningrad: Nauka. 303 p. (in Russian).

10. Liszt F. (1959) Izbrannye statyi [Selected Articles]. Moscow. 465 p. (in Russian).

11. Losev A.F. (1991) Dialektika mifa [The dialectics of myth]. Filosofiya. Mifologiya. Kultura [Philosophy. Mythology. Culture]. Moscow. P. 21-186. (in Russian).

12. Mandelstam O. (1967) Razgovor o Dante [Talk about Dante]. Moscow. 165 p. (in Russian)

13. Muzykalnaja estetika Germanii [The musical aesthetics of Germany]. In 2 vols. (1961). V. 1. Moscow. 415 p. (in Russian).

14. Nádor T. (1988) Esli by List vel dnevnik... [If Liszt kept a diary...]. Budapest. 349 p. (in Russian).

15. Roshchenko E. G. (1998) Dante i List: metamorfozy mifologemy puti [Dante and Liszt: metamorphoses of the mythological path]. Aspekty istorychnoho muzykoznavstva [Aspects of historical musicology]. Kharkov. P. 79-89. (in Russian).

16. Roshchenko E. G. (2000) Concepts of the finite and infinite in the philosophy and art of romanticism [Konceptsii konechnogo i beskonechnogo $\mathrm{v}$ filosofii $\mathrm{i}$ iskusstve romantizma]. Problemy osobystisnoi oriientatsii 
pedahohichnoho protsesu [Problems of personal orientation of pedagogical process] (collection of scientific works). Kharkov. P. 194-205. (in Russian).

17. Roshchenko E. G. (2000) K probleme genezisa zhanra romanticcheskogo fragmenta [The genesis of the romantic fragment genre]. Teoriia $i$ praktyka pedahohichnoho protsesu [Theory and practice of pedagogical process] (collection of scientific works). Kiev. P. 218-228. (in Russian).

18. Roshchenko E. G. (2000) Pervyy tsikl romanticheskogo mifa o Dante i sonata-fantaziya F. Liszt [The first cycle of the romantic myth of Dante and the sonata fantasy of F. Liszt.]. Muzychne mystetstvo $i$ kultura. Naukovyi visnyk [Music art and culture. Scientific Bulletin]. in. 1. Odessa: Astroprint. P. 59-67. (in Russian).

19. Roshchenko E. G. (1999) Sonata-fantaziya F. Lista: po sledam "opasnogo stranstviya" [Fantasy sonata by F. Liszt: in the wake of the "dangerous journey"]. Ferenc Liszt ta pianistychna kultura $20^{\text {th }}$ stolittia [Ferenc Liszt and the pianist culture of the twentieth century]. Kharkov. 1999. P. 71-76. (in Russian).

20. Savitskaya N. V. (2009) Vikovi aspekty kompozytorskoi zhyttietvorchosti [Age-related aspects of composer's life-creation] (dissertation of Doctor of Art Studies). Kyiv: P. I. Tchaikovsky National Music Academy. (in Ukrainian).

21. De Sanctis F. (1963) Istoriya italyanskoy literatury [History of Italian literature]. In 2 vols. Vol. 1. Moscow. 535 p. (in Russian)

22. Schelling F. (1966) Filosofiya iskusstva [Philosophy of art]. Moscow: Mysl. 496 p. (in Russian)

23. Schlegel F. (1990) Iz "Ateneyskikh fragmentov" [From the Athenaic Fragments]. Zarubezhnaya literatura 19th veka. Romantizm [Foreign literature of the 19th century. Romanticism]. Moscow. P. 41-45. (in Russian).

24. Schlegel F. (1990) Iz "Kriticheskikh (likeyskikh) fragmentov" [From the "Critical (Lycian) fragments"]. Zarubezhnaja literatura 19th veka. Romantizm [Foreign literature of the $19^{\text {th }}$ century. Romanticism]. Moscow. P. 37-40. (in Russian).

\section{Information about the author:} Olena Roshchenko,

Doctor of Art Criticism (hab. dr.), Habilitated Professor, HoD of History and Theory of Music Kharkiv State Academy of Culture, Kharkiv 4, Bursatski Uzviz, Kharkiv, 61057, Ukraine orcid.org/0000-0002-6048-6335 